\title{
Statutory Rape Law in Chile: For or Against Adolescents?
}

\author{
Claudia Ahumada, LLM \\ World AIDS Campaign, Women's Campaign Coordinator \\ E-mail: claudia.ahumada@utoronto.ca
}

\begin{abstract}
This article sets forth the interests and conflicts involved in the current Chilean law on statutory rape. Through a thorough investigation of the conceptualization, implementation, and current life of this legislation, the possible effects of the Chilean case on adolescents' rights is investigated and evaluated. Examining the development of this law and its related policy, and if their consequences conflict with the Chilean Constitution or international and regional human rights conventions allows us to evaluate the merits, utility, and potential problems of such legislation. A detailed investigation of the social and legal data available, as well as the concrete liability implications reveals that the policy which implements the Chilean statutory rape provision is in violation with domestic and international human rights law.
\end{abstract}

Keywords: Statutory rape, Adolescents, Sexuality, Rights

\section{Introduction}

In the past few years, a tendency to increase the age of consent in statutory rape laws has arisen. Chile is one of the countries where, in 2004, the Criminal Code was modified to increase said age to 14, whereas the previous age was set at 12. (Note 1) Through this law, sexual intercourse with any minor under the age of fourteen, regardless of whether the parties believed it was consensual, is considered a crime.

This legislative modification was significant for Chilean society, as it took place at a time when it was experiencing feelings of outrage and horror, in the face of high profile sexual abuse and pornography cases._(Note 2) In this context, the law was presented as a way to protect children and adolescents from such situations. (Note 3)

The adoption of this law led to the creation of a policy by the Prosecutors office which establishes the legal obligation of health care professionals and teachers to report any adolescent under the age of fourteen who is sexually active or seeks contraceptives. (Note 4) Once reported, it is the prosecutors' responsibility, in accordance to Chilean law (Note 5), to lead the investigation of possible criminal activity, such as the existence of statutory rape. (Note 6)

Given the policy through which this law is being implemented, it is relevant to consider the effects that it may have on adolescents and their human rights. Throughout this article, it will be argued that the Chilean provision on statutory rape and, in particular, the elected mode of implementation violates adolescents' human rights. Specifically, it will be said to violate adolescents' right to confidentiality, information, health, as well as equality and non-discrimination, as recognized both by domestic and international human rights law.

\subsection{The close-in-age exception}

When examining statutory rape law, it is relevant to consider whether a close-in-age exception has been established. In the case of Chile, the law which establishes a system of responsibility for adolescents who infringe the criminal law contains what is known as a "close-in-age" exception. (Note 7) By ways of this exception, it is established that adolescents may not be criminally prosecuted for rape of a person under the age of fourteen, so long as the age difference between the victim and the accused doesn't exceed two years in the case of rape, and three in the case of other sexual conducts. (Note 8) The law also requires that there be no use of force, intimidation, the victim not be deprived of consciousness, advantage is not taken of the incapacity to oppose resistance, and there is no abuse of the loss or mental disturbance of the victim. Additionally, there must not be abuse of a relationship of dependency of the victim, or of the abandoned state of the victim or of the inexperience or sexual ignorance of the victim. (Note 9)

In other words, the close-in-age exception admits the possibility of consensual sex amongst peers with a person under the age of fourteen, thus avoiding criminalization. While relevant, the limitation of this exception to a two-year difference amongst parties may prove to be problematic. That is, while age based distinctions may be useful they are also necessarily arbitrary to a degree. (Note 10) This is revealed by the way in which statutory rape law addresses different cases. For example, it establishes that it is legal for a fifteen year old boy to engage in consensual sexual intercourse with a thirteen year old girl, but it is not legal for a sixteen year old boy to have sex with that same thirteen year old girl. 
A situation such as the above poses certain difficulties. For instance, if it is the same thirteen year old girl in both cases, and she is recognized as capable of freely consenting to engage in sexual intercourse in the first scenario, what is the justification for denying this capacity in the second scenario? Is the capacity and level of maturity required to be able to freely consent to engage in sexual activity different depending on whether the expected partner is two or three or even five years older?

While the initial response may be negative, it can be argued that the rationale behind this norm is that it presupposes that a person with over two years of age difference with their partner, who is under the age of fourteen, may be able to exert undue influence on their partner, thus making consent impossible. In certain cases, this may occur. For example, if a forty year old man engages in sexual intercourse with a thirteen year old girl, and this intercourse is said to be consensual, one may very well inquire as to how the forty year old man was able to use his mature age and experience as a tool to wrongfully induce the thirteen year old girl into apparent "consensual" sexual intercourse.

In cases where the age difference is so great, the law would appear to have reason to presume that sexual intercourse between such parties was not, in essence, consensual. Nonetheless, it is necessary to distinguish between the amount of undue influence and pressure that a person with a twenty or thirty year age difference may exert on a person under the age of fourteen, and that which may be exerted by a person of an age that also forms part of the span of adolescence, or even, in accordance to the Convention on the Rights of the Child, a child themselves.

\section{Adolescents' sexuality in the Chilean legal context}

Chilean society can be said to be marked by a variety of strong influences and historical events. Its political history is rampant with dictatorships, the most recent one dating from the year 1973 to 1990 . This period was a time where the most basic rights were unacknowledged, leading to mass human rights violations. (Note 11)

In this time, adolescents and their rights were not a priority on the public agenda. Once the dictatorship ended, the newly democratic government had the task of leading the country through the process of reconciliation, while at the same time providing justice. As time passes, governments and society have begun to widen the horizon of issues on the public agenda, reaching a point where the dictatorships legacy of human rights violations can no longer be said to be the only topics of the agenda.

One of the issues that arose in this context is the regulation of gender and sexuality. Feminist groups have taken the initiative to demand that gender equality be recognized in law and sexual and reproductive rights be acknowledged, (Note 12) in keeping with the international human rights treaties signed and ratified by Chile.

Though some significant legal changes have been made (Note 13), there is still a long way to go. Indeed, to the political legacy of the dictatorship, one must add the strong influence of the Roman Catholic Church. The Catholic Church acts as a strong conservative force, exerting significant influence over cultural values and political elites, particularly in matters of sexuality. (Note 14)

In such a context, legal actions contending sexuality issues tend to be wrought with controversy which tend to delay, if not impede, their success. For example, conservative actions to stop the distribution of the emergency contraception pill took place from 2001 to 2008. (Note 15)

Regarding adolescents, international human rights bodies have expressed particular concern about Chile's compliance with its obligations as State party to the Convention on the Rights of the Child (CRC) and Convention on Economic, Social and Cultural Rights (CESCR). Issues highlighted include the rate of teenage pregnancy and teenage mothers that drop out of school (Note 16); the lack of information, counselling and preventive programmes on reproductive health, including the lack of adequate access to contraceptives(Note 17), and the persistence of authoritarian and paternalistic attitudes towards children. (Note 18)

It is this last point that impacts the general treatment of adolescents in Chile, as these attitudes permeate different spheres of adolescents' lives, in a way which may affect their status as rights bearers. (Note 19)As noted by the Committee on the Rights of the Child:

“(...) due to traditional and paternalistic attitudes still widespread in the country, children are not encouraged to express their views and that, in general, their views are not heard nor given due weight in decisions affecting them in the family, at school, in the community and in social life at large." (Note 20)

The lack of recognition of adolescents as rights bearers, leads to common public controversy whenever the issue of adolescents' sexuality is raised, whether it be at the judicial, legislative or policy level. At the judicial level, sexuality is viewed under a moral lens, which circumscribes it to adults. An example of this can be seen in a case brought against a Chilean television station, for televising a segment which showed adolescents playing a game called "cultural striptease", in which they took off certain pieces of clothes and danced sensuously. (Note 21) The Court ruled that this segment was not acceptable, stating that the segment invited minors to naturally follow behaviours that are more 
appropriate to the adult world, while sending the message that sexuality is free of affection. (Note 22) This case provides us with an example of the tensions that arise when the issue of adolescents' sexuality is on the table.

\section{The rationale of Statutory Rape Law}

The understanding of what constitutes a sexual offence varies over time and cultures. Indeed, all sexual crimes are, to a degree, socially constructed, in the sense that they indicate what is considered as "normal", while reflecting society's fears and prejudices. (Note 23) Thus, the definitions of sexual crimes portray what is considered to be sexually appropriate behaviour. (Note 24)

One of the main sexual crimes is rape. Though recognized today as a sanctioned in order to protect women - and sometimes men -, it arose as a way to protect the economic interests of males and to perpetuate male dominance over females. (Note 25) Rape, understood as non-consensual sex, continues to be a prevalent crime, both among young and older women. (Note 26) This raises particular concerns in regards to young adolescents, as they may be less prepared to confront situations of non-consensual sex, as well as to deal with them if they do occur. (Note 27)

In light of this, taking special measures to protect children and adolescents from rape appears to be reasonable. One of these measures may be the adoption of statutory rape laws. These laws have existed since the seventeenth century and stem from a Western medieval notion that it was necessary to preserve girls' chastity in order for them to be marriageable. (Note 28) Originally, the object of protection of these laws was a girls' virginity, though today they are held to serve as a means to protect children. (Note 29)

These laws criminalize sexual contact with a minor, (Note 30) by presuming them incapable to consent to sexual activity and/or intercourse. (Note 31) In other words, they invalidate consent, whereas, in non-statutory rape cases, consent is a defence to rape. At first these laws only made this presumption in regards to girls, but the modern tendency is to also include boys. Nonetheless, the majority of statutory rape cases still affect younger girls, rather than boys. (Note 32)

Currently, different interpretations of statutory rape law and its value may be observed. On the one hand, there is a growing awareness of the need to put a stop to child sexual abuse, (Note 33) which in turn has led to efforts to create or strengthen mechanisms that will serve this purpose. One of the ways in which the problem of child abuse is being confronted is through statutory rape laws and, moreover, by raising the age of sexual consent involved in these laws.

By raising the age of sexual consent, the scope of statutory rape is extended to include a wider age-group. The expectation is that, by raising the age of sexual consent, young people will be protected not only from sexual abuse, but also from teenage pregnancy and sexually transmitted infections (STI's.) (Note 34) In addition, those in favour of raising the age of sexual consent have argued that to not do so is to incite adolescents to initiate sexual activity at a still earlier age. (Note 35)

On the other hand, there are those who argue that, while condemning sexual abuse and rape is a commendable goal of any legislation, statutory rape law is not successful in doing so and, rather, has other negative effects. (Note 36) Indeed, statutory rape has long faced criticism for failing to distinguish between a brutal rape and a teenage romance. (Note 37) As Levine puts it:

"(...) statutory rape is not about sex the victim says she did not want. It is about sex she did want but which adults believe she only thought she wanted because she wasn't old enough to know she did not want it." (Note 38)

In this sense, statutory rape serves as a means to impose a certain morality, under which young adolescents should not be having sex. (Note 39) According to these moral norms, traditional notions of adolescence, which equate adolescents to helpless children, are reinforced. At the same time, since statutory rape laws continue to overwhelmingly affect girls, these laws also reinforce traditional images of girls as in need of protection. (Note 40)

Detractors from statutory rape laws also criticize the fact that they take away the agency of adolescents, as proceedings tend to be initiated by upset parents, who are not happy about their little girl having sex. (Note 41) This victimization is said to be disempowering, particularly when the adolescent felt she was engaging in consensual sex. (Note 42) Instead of denying adolescents ability to consent to sex, the law should recognize that many young people are already having sex or will choose to do so and therefore provide the support, information and services needed for them to make this choice responsibly. (Note 43)

Statutory rape laws can be viewed as part of a broader tendency to criminalize sexuality. Since ancient times, the discourse of sexuality has been subjected to powerful moral ideologies which construct entire systems to keep sexuality in check. (Note 44) In addition, history attests to a broad movement to use criminal law as a tool to enforce religious and traditional morality. (Note 45)

\section{Statutory rape law and Human Rights}

The effects of the Chilean provision on statutory rape may be examined from two perspectives. First of all, one may consider the effects produced by the law per se. In the second place, one may look at the effects generated by the way in 
which the law is being implemented. While the effects produced by the law itself raises issues of criminal law, those that arise from its implementation have to do with matters of human rights. This article will focus on these last issues, though the effects generated by the law itself will also be briefly addressed.

In terms of the effects produced by the law per se, the desired effect is for it to protect adolescents from sexual abuse. Though this may be accomplished to some extent, it also places an inherent risk of prosecution on adolescents who engage in sexual intercourse with a peer under the age of fourteen. The presence of this risk is problematic and gives rise to particular concern due to the fact that rape is one of the crimes which is most severely punished under Chilean law. Perpetrators may be convicted to up to twenty years of imprisonment. (Note 46)

Given that the law does not admit the possibility of consent, the teenage boyfriend of a thirteen year old girl may, under this law, be prosecuted and condemned as a rapist for engaging in consensual sexual intercourse. Conversely, the person under fourteen who engaged in sexual activity will be stigmatized as a rape victim, regardless of that person's feelings and belief that they have engaged freely and consensually in said activity.

In addition to this risk, posed by the law in itself, concerns also arise upon the examination of the way in which the statutory rape provision is being implemented. As noted earlier, this law was followed by a policy which orders health care professionals and teachers to report any indication of sexual intercourse to the prosecutor.

Regarding health care professionals, this policy has led to the denial of sexual and reproductive health services. This is so because health care providers, when faced with the option of either reporting an adolescent to be investigated on the charge of rape or denying services, choose what seems as the lesser evil: denying service. (Note 47) Whether they choose one option or the other, adolescents' human rights are implicated. Particularly, concerns about adolescents' right to confidentiality, information, health, and equality and non-discrimination, arise, as will be seen in sections 4.1., 4.2., 4.3. and 4.4.

Before proceeding to examine these rights, it is relevant to consider that any affectation of adolescents' rights in this context is of particular concern, given the Chilean statistics related to adolescent's sexual activity. Indeed, according to a study produced by the National Institute of Youth (Instituto Nacional de la Juventud, INJUV), the majority of young people have a partner (Note 48) and the majority of young people have also had sexual intercourse. (Note 49)

Though the majority of Chilean youth have sexual intercourse for the first time between the ages of fifteen and 18 $(62,6 \%), 13,7 \%$ have had sexual intercourse before the age of fifteen(Note 50) and are, therefore, likely to fall into the category of what statutory rape law views as illicit sexual activity. It is also relevant to note that there is a tendency for a decrease in the age at which most Chilean youth have sexual intercourse for the first time. (Note 51) With this context in mind, the following section will examine the specific rights implicated through the implementation of the Chilean provision on statutory rape.

\subsection{Adolescents right to confidentiality}

The statutory rape provision of Chile, along with the policy that arose from it, may be evaluated based on the way in which it may affect different rights. One of the rights that may be implicated is adolescents right to confidentiality, particularly in the sexual and reproductive health context.

In the health care context, confidentiality means that all and any information shared between the health care provider and the patient/client must remain within the consultation. (Note 52) While the right to confidentiality has been recognized for all people (Note 53) regardless of age, it is important to become familiar with the way in which this right has been enshrined for adolescents specifically, given the particular challenges that arise for this age group.

The right to adolescents' confidentiality when seeking both information and services regarding sexual and reproductive health services has been recognized in a variety of international forums, as well as addressed in different judicial cases. Though these cases do not create legal precedent for Chile, they constitute a relevant means to understand the way in which adolescents' confidentiality has been interpreted and upheld worldwide.

An example of such a case is that of Gillick v. West Norfolk and Wisbech Area Health Authority. (Note 54) This case was originated through an action brought by the mother of five daughters below the age of sixteen, who sought the declaration on behalf of the Court that a circular that stated that a doctor could lawfully prescribe contraceptives to a girl under sixteen, without parental consent, was unlawful. The House of Lords, in a decision with a 3:2 majority, determined that it was. When reviewing this case, one of the judges, Lord Fraser noted that the capacity and autonomy of young people must be understood according to the social context, and that it could not be thought that English teenagers would be under strict parental control until reaching the majority of age. (Note 55)

At the same time, another judge, Lord Scarman stated that doctors did not incur in criminal responsibility for prescribing contraceptives to adolescents below the age of sixteen without parental consent, given that the doctors do not instruct adolescents to have sex, but rather act guided by their clinical judgement aimed at protecting the health of 
their patients. In this way, the case upheld adolescent's right to confidentiality in the context of sexual and reproductive health services. (Note 56)

Another relevant case is that of AID FOR WOMEN et al. vs. Nola Foulston et al. (Note 57) This case was brought by the Centre for Reproductive Rights on behalf of a group of health care providers and counselling services, challenging Kansas's attorney general's interpretation of the child abuse reporting statute. This interpretation called for doctors and school counsellors, among others, to report all suspected sexual activity involving anyone under the age of 16 as evidence of child abuse. (Note 58) The Kansas District Court ruled against said interpretation, noting that reporting all teen sexual activity infringed their right to privacy and was not consistent with the goal of the statute. (Note 59) Rather, the focus should be put on identifying true victims of abuse, being health care providers in a unique position to determine whether such abuse exists. (Note 60) Thus, health care providers should be able to retain the discretion of whether or not to report based on signs of sexual abuse. (Note 61)

These judgments contribute to an understanding of what adolescents' confidentiality means, as well as why it is relevant. The analysis of these cases leads to the conclusion that adolescents' right to confidentiality is not only recognized internationally, but that ensuring that it is upheld is of particular importance when it comes to their reproductive and sexual health. Indeed, the Committee on the Rights of the Child has also highlighted the importance of ensuring adolescents' confidentiality, including on health matters. (Note 62)

Adolescent's right to confidentiality in regards to their sexual and reproductive health can also find legal basis in Chilean law, chiefly in the Constitution (Note 60) as well as in the Code of Medical Ethics. This Code establishes doctor's duty of confidentiality towards their patients (Note 64) and also notes that the opinions of minors must be taken into consideration, according to their age and level of maturity. (Note 65)

Exceptionally, doctor's may be allowed to reveal information related to their patients if the patient has a sickness where reporting is mandated; if the Courts order them to do so; when required for birth or death certificates; when it is absolutely necessary to avoid harm to the patient or others; and when it is necessary for their own defence in Court. (Note 66) Similar exceptions can be found in both Chile's Sanitary Code and Chile's Penal Process Code, which order that the duty of confidentiality be forgone in cases where there is the obligation to protect the health of the population(Note 67), or when the professionals must report the existence of a crime or the signs of one. (Note 68)

The Chilean statutory rape provision puts us in this last hypothesis. That is, it would be a case where professionals have the legal obligation to report the existence of a crime (statutory rape), or the signs of one. Based on this, it would appear that doctors are protected by the law in surrendering their duty of confidentiality.

However, according to the Chilean provision on statutory rape, the crime consists of engaging in sexual intercourse with any person under the age of fourteen. (Note 69) The law does not penalize contraception, nor does it view the person under the age of fourteen as perpetrator or criminally liable. Consequently, doctors and health care providers broadly are under no obligation to denounce young teens who seek contraceptives or who disclose their intent to engage in consensual sexual activity. Quite to the contrary, in the absence of true signs of abuse, their obligation is to uphold confidentiality.

\subsubsection{Implications of statutory rape law on adolescents' right to confidentiality}

In the process of examining the implications of the Chilean statutory rape provision on adolescents' confidentiality, a distinction must be drawn between the implications generated by the law per se and those that result from its current mode of implementation.

Regarding the implications of the law itself, as already seen, they consist of the inherent risk of prosecution. In order for such prosecution to take place, a case of sexual intercourse with a person under the age of fourteen must be reported to the prosecutor. If this report comes from a health care provider, the issue of confidentiality arises.

This leads the focus to shift to the policy designed to implement the law, which orders health care professionals to report to the prosecutor any sexual intercourse with a person under the age of fourteen or who is seeking contraceptives. This policy makes the surrender of confidentiality mandatory, without allowing room to consider whether sexual intercourse is consensual or not.

Though disclosure is meant to protect adolescents from sexual abuse, whether this is an effective and appropriate way to do so is subject to discussion. Indeed, there are those who argue that denying adolescents' confidentiality is neither an effective nor appropriate means, as it may lead them to not access these services. (Note 70) Such a response finds basis in studies which show that confidentiality concerns are a major reason why adolescents' don't access health care services. (Note 71) The threat of criminal prosecution may be expected to heighten these concerns, given that adolescents should not be expected to want to expose themselves or their partners to criminal charges. In regards to this, the right to not incriminate one-self also raises challenges. (Note 72) 
This context may lead to sexual activity among adolescents to be driven underground, thus defeating the protective purpose of the law. The consequences of this are dire, as it may lead to a heightened number of teenage pregnancies, unsafe abortions and untreated STI's, including HIV and AIDS. (Note 73) On the contrary, if confidentiality were to be upheld, adolescents would be encouraged to access health services. When doing so, health care professionals would have the opportunity to provide the guidance and information that adolescents need to make healthy, informed and responsible decisions about their sexuality. (Note 74)

\subsection{Adolescents right to information}

The right to information is internationally recognized as an aspect of freedom of expression, which is established in the Chilean Constitution as a fundamental right. (Note 75) In order to understand how the right to receive information pertaining to sexual and reproductive health has been addressed, it is useful to consider the case of Open Door Counselling and Dublin Well Woman v. Ireland. (Note 76) Though this case falls under the jurisdiction of the European Court of Human Rights, which does not have jurisdiction over Chile, it is helpful to consider as a means to understanding how this right has been framed internationally.

This case examined whether an injunction preventing two women's health clinics from disseminating information to women in Ireland on legal abortion services provided outside of Ireland violated Article 10 (Note 77) of the European Convention, and ultimately ruled that it did. In its resolution, the Court recognizes that restrictions on such information could cause some women to seek or obtain abortion at a later stage in their pregnancy, which would, in turn, threaten their health. Additionally, the Court noted that withholding information may have particularly negative effects on women of insufficient resources or education that would enable them to access alternative sources of information.

Though this case refers specifically to abortion, its reasoning may be extended to other situations which may lead to withholding information on sexual and reproductive rights matters. Thus is the case of the policy which followed the current Chilean provision on statutory rape, which, due to mandatory reporting and the threat of prosecution, leads to withholding services - and consequently information - or adolescents simply not going to avoid this threat.

The importance of upholding adolescents' right to sexual and reproductive health information has also been acknowledged by international bodies, such as the Committee on the Rights of the Child. The Committee has held that governments should provide and ensure that adolescents have access to sexual and reproductive information, regardless of their parents or guardians consent. (Note 78)

\subsubsection{Implications of statutory rape law on adolescents' right to information}

The implications on adolescents' right to information on sexual and reproductive health matters stem from the consequences being generated by the policy which implements the statutory rape provision. As noted, this policy calls for mandatory reporting to the prosecutor. In order to avoid the need to report, health care professionals sometimes choose to deny service to younger adolescents. (Note 79)

Though this denial may be argued to be caused by the doctors, a closer look reveals that it stems from the policy which puts them in the position to report adolescents to the prosecutor, against their better judgement. Indeed, rather than reporting for public health purposes, this reporting is for crime control, even in the absence of any true crime.

Either way, the denial of services to adolescents can place barriers to their ability to access information on sexual and reproductive health matters. This can raise concerns because this information serves as a means to avoid certain health risks, such as unwanted pregnancies, unsafe abortions, and STI's, including HIV and AIDS. (Note 80) Access to information also helps adolescents anticipate the consequences of their actions and develop the capacity for long-term planning. (Note 81)

Studies have also shown that adolescents who receive comprehensive sexuality education are more likely to make informed and responsible decisions about their sexuality. (Note 82) Specifically, they are more likely to delay sexual activity, less likely to engage in risky sexual practices, more likely to use condoms and other contraceptives, have fewer sexual partners, and have sex less often than those who do not. (Note 83)

Health care professionals play an important role when it comes to providing scientific, accurate, information regarding sexual and reproductive health. Their role is particularly relevant in regards to adolescents, who many times are exposed to a great amount of misinformation or may receive no information at all.

When health care professionals that are faced with the choice of reporting an adolescent to the prosecutor and not providing service, choose this last option, adolescents' right to information is infringed upon. Indeed, though denying service in order to avoid possible prosecution of the minor, may be the lesser evil, fundamental human rights - such as the right to information - should not be subject to a system of "either/or".

Moreover, even if health care professionals do not deny services, adolescents may abstain from seeking them, given the confidentiality concerns discussed in the above section. In such circumstances, they would again be left without access to essential sexual and reproductive health information. 
Though it is possible to argue that such information is available and it is adolescents that choose not to access it, one must examine this matter in more depth. That is, since the foreseeable consequence of accessing this information is criminal prosecution, a true choice does not exist. Thus, their right to information is inherently affected by the policy on statutory rape. Indeed, adolescents' right to information would be better upheld by providing sexuality education and guidance, instead of placing the threat of criminal law on those who engage in sexual intercourse. (Note 84)

\subsection{Adolescents' right to health}

While the Chilean Constitution does not establish the right to health, it does recognize the right to the protection of health(Note 85) The right to the protection of health can be interpreted as encompassing the right to health, in certain cases. Such an interpretation was recently given by the Constitutional Court of Colombia. (Note 86)

In this case the Court determined that a Penal Code provision that criminalized abortions performed on adolescents' below the age of 14, even with their consent, was unconstitutional. (Note 87) It acknowledged that even when the right to health is not formally included in the list of rights established in the Constitution, it acquires this nature when it is connected to the right to life, that is, when such protection is necessary to guarantee the continued dignified existence of the person. (Note 88)

Whether Chilean courts will follow this interpretation, though, remains to be seen. Regardless, there is a legal basis to sustain that Chile must uphold the right to health. This basis may be found in the Convention on Economic, Social and Cultural Rights (CESCR), which has been ratified by Chile and is currently in force. The CESCR establishes this right explicitly. (Note 89) It is also important to note that the Committee charged with monitoring the implementation of the CESCR has acknowledged that the right to health includes the right to reproductive health. (Note 90)

When examining the scope of the right to health, the CESCR Committee has established that it contains four interrelated and essential elements. These elements are: availability, accessibility, acceptability and quality. (Note 91) Therefore, for the right to health to be fully respected, these four elements must be upheld.

\subsubsection{Implications of statutory rape law on adolescents' right to health}

Though the right to health is composed of the four elements seen above, for the purpose of this article, only two will be examined. These are: accessibility and acceptability. This is so because neither the availability of health services, nor the quality is put in question.

The first element to be examined is accessibility. This element is composed of four over-lapping dimensions:

a. Non-discrimination: health facilities, good and services must be accessible to all, especially the most vulnerable or marginalized sections of the population, in law and in fact, without discrimination on any of the prohibited grounds.

b. Physical accessibility

c. Economic accessibility (affordability)

d. Information accessibility: accessibility includes the right to seek, receive and impart information and ideas concerning health issues. (Note 92)

Though it is possible that several of these dimensions may be problematic for Chilean adolescents, it would exceed the scope of this article to examine them all. The purpose here is to focus solely on those aspects that may be affected by the implementation of the statutory rape provision. Therefore, physical and economic accessibility will not be addressed. The matter of non-discrimination and information accessibility, though, may be implicated.

The issue of non-discrimination will be analyzed in the following section, so will not yet be discussed. As for information accessibility, this dimension of the right to health relates directly to the right to information, examined in the above section. Therefore, when adolescents' are denied health services, both their right to information and health are affected.

Another dimension of the right to health that may be affected by the implementation of the statutory rape provision is acceptability. The meaning of acceptability has been examined by the CESCR Committee, which reasoned as follows:

"Acceptable services are those that are delivered in a way that ensures that a woman gives her fully informed consent, respects her dignity, guarantees her confidentiality and is sensitive to her needs and perspectives." (Note 93)

Applied to adolescents, acceptability means that delivery of health services must ensure fully informed consent, respect of dignity, confidentiality and sensitivity to their needs and perspectives. As already seen, the implementation of the statutory rape provision compromises adolescents' confidentiality. Thus, this dimension of acceptability is not satisfied. To this, it is necessary to add that these services do not appear to be sensitive to adolescents' needs and perspectives, either, as they fail to consider how the denial of services or the alternate threat of prosecution may affect them. 


\subsection{Adolescents right to equality and non-discrimination}

The Constitution of Chile recognizes a legal right to equality and non-discrimination. (Note 94) For the purposes of this article, it is relevant to consider whether age-based discrimination may be considered unlawful. Though "age" is not specifically enumerated as grounds of discrimination by any human rights treaty, it is a factor which may be called upon when establishing differential treatment. Indeed, the Convention on Civil and Political Rights, the American Convention and the Chilean Constitution all have open-ended equality provisions(Note 95), meaning that other grounds of discrimination, such as age, may be invoked.

The dismal effects of age based discrimination are slowly becoming acknowledged by the international community, leading several human rights treaty bodies to address age-based discrimination regarding sexual and reproductive health. For instance, both the Committee on the Rights of the Child and the CEDAW Committee have lamented adolescents' lack of access to sexual and reproductive health information and services, calling upon governments to eliminate age-based discrimination. (Note 96)

\subsubsection{Implications of statutory rape law on adolescents' right to equality and non-discrimination}

The statutory rape provision at hand makes a distinction based on age. That is, it draws a distinction between adolescents under the age of fourteen and those above that age. This distinction consists of denying that anyone below the age of fourteen has the capacity to consent to sexual intercourse. In other words, one group (those younger than 14) are not provided with a certain right or service that the second group (those older than 14) are provided with.

The policy which arose from the statutory rape provision extends this distinction. This is done by denying the confidentiality, right to information and health of adolescents below this age who are sexually active or request contraceptives.

To consider whether this distinction is unlawful under the Chilean Constitution, one must consider the way in which the equality clause is interpreted domestically. Currently, equality is understood as a limit to State powers and as a defence mechanism in cases of arbitrary discrimination (Note 97). What is specifically prohibited by the Chilean Constitution, then, is arbitrary discrimination, understood as an unjustified or unreasonable difference in treatment. (Note 98) In turn, difference in treatment will be deemed unjustified or unreasonable if it lacks sound reason, a legitimate aim and proportionality (Note 99).

The distinction in this case is based on "age". At first glance, this may appear to be an objective criterion. Indeed, it certainly is a convenient way to measure maturity. (Note 100) Nonetheless, a closer look will reveal that "age" is not purely objective. This is so because adolescents of the same age tend to have different levels of maturity. The Constitutional Court of Colombia has elaborated on this point in a case which sought to determine whether a Penal Code provision that criminalized abortions performed on adolescents' below the age of 14, even with their consent, was unconstitutional. (Note 101) In its ruling, the Court established that it was and warned that "age" is not an absolute criterion. Consequently, the Court has established that "the higher the intellectual-emotional capacities are, the lower the legitimacy of the intervention measures over the decisions made based on these." (Note 102)

Though Colombian jurisprudence does not generate any legal obligations for Chile, the reasoning exposed in the above judgement also finds resonance in one of the principles of the $\mathrm{CRC}$, which Chile is legally bound to. This principle is that of evolving capacities. It is broadly contained in article 5 of the Convention, which establishes that:

"States Parties shall respect the responsibilities, rights and duties of parents or, where applicable, the members of the extended family or community as provided for by local custom, legal guardians or other persons legally responsible for the child, to provide, in a manner consistent with the evolving capacities of the child, appropriate direction and guidance in the exercise by the child of the rights recognized in the present Convention."

Based on this principle, States have the obligation to consider the level of maturity of individuals. This must be done on a case by case basis, as cognitive capacities vary from individual to individual.

Not withstanding the above, there are some common factors that health care providers, amongst others, can look at when assessing the evolving capacities of the child/adolescent. In the context of sexual and reproductive health services for adolescents, what must be determined is whether the adolescents' capacities have evolved enough to be able to access these services in confidentiality and make their own decisions.

While health care providers must assess this on an individual basis and also consider the possible harm to the adolescent or others, they must start there inquiry on the amply recognized premise that if a young person accesses services on their own accord, this signifies their to seek care and thus to make their own choices regarding care (Note 103). Not recognizing this generates situations where an adolescent "engages in a 'mature' sexual relationship without the 'mature' knowledge of how to protect him or herself." (Note 104)

Given that the policy that implements the Chilean statutory rape provision calls for mandatory reporting to the prosecutor, without allowing room for health care professionals to consider the evolving capacities of the adolescent, 
this principle is neglected. The high stakes involved in the case of statutory rape, which include criminal prosecution, call for a more flexible norm.

Indeed, this legislation, as well as its aim to protect children and adolescents, coincides with a specific image of adolescent sexuality. That is, adolescents are assumed and expected to be ignorant of sexual matters. The policy which followed the statutory rape provision, which calls for mandatory reporting regardless of whether sexual intercourse was consensual, can be said to be an example of the moral panic that surges around adolescent sexuality.

This policy acts as a means of preserving the traditional image of childhood and adolescence, as chaste and innocent. This scenario is typical of parentalistic societies, such as the Chilean one, which tend to be reluctant to recognize that young adolescents' can make responsible decisions regarding their sexuality. (Note 105) Such an aim exceeds the limits of legitimacy, denying adolescents' rights and autonomy.

\subsubsection{Gender discrimination}

Sexuality is constructed in a fundamentally gendered way. (Note 106) The traditional image of female sexuality is essentially passive, as girls are seen as victims or objects of desire. Male sexuality, on the other hand, is seen as active, natural and uncontrollable. These images of female and male sexuality are reflected in the Chilean policy on statutory rape, leading to gender discrimination. Indeed, statutory rape laws generally affect girls. (Note 107)

The mandatory reporting ordered in the Chilean policy fails to distinguish situations where adolescents, including female adolescents, may have chosen to freely engage in sexual intercourse. Reporting in such circumstances leads to the victimization of adolescent girls and, consequently, disempowers them. It sends the message that they are not free to make decisions about their sexuality. Thus, the traditional image of female sexuality is re-enforced. This can be argued to constitute gender discrimination, in the terms set out by CEDAW. (Note 108)

\section{Conclusions}

This article has attempted to address the effectiveness of the Chilean provision on statutory rape in fulfilling its declared goal of protecting young adolescents from potential sexual abuse and rape. A careful analysis has revealed that the provision does not adequately accomplish this goal, as in its attempt to protect it violates adolescents' fundamental human rights. The statutory rape policy provision lacks proportionality and denies adolescents autonomy, leading, in turn, to the affectation of their human rights.

The health care community experiences challenges in fulfilling adolescent's sexual and reproductive health needs with a highly restrictive policy: sexual and reproductive health services to any adolescent under the age of 14 is not permitted without reporting to the prosecutor. This results in the denial of much needed services and the heightened vulnerability of young adolescents.

The lack of flexibility in the policy implementing the statutory rape law, accompanied by the threat of prosecution, places adolescents in a vulnerable position because they are left without health services that would enable them to make responsible, healthy choices. In cases where service is provided, medical decision making would be highly discretionary and reporting would ultimately depend on the good will of the practitioner, thus submitting both the adolescent and the health care provider to a high degree of uncertainty.

In such a context, it is necessary to seek the abolition of the policy which seeks to implement the statutory rape norm. Establishing measures to evaluate the extent to which the law impacts adolescents and their rights would likely contribute to a heightened degree of awareness regarding the challenges that this policy generates. Additionally, it would allow for a genuine respect of adolescents' human rights, while at the same time achieving the original legislative goal of protecting young adolescents.

\section{References}

Advocates for Youth and the Sexuality. (2001). Toward a Sexually Healthy America: Roadblocks Imposed by the Federal Government's Abstinence-Only-Until-Marriage Program. New York: SEICUS.

American Convention on Human Rights (1969). Available: http://www.hrcr.org/docs/American_Convention/oashr.html (November 22, 1969).

Baker, T., Hobcraft, G. (2006). Special needs of adolescent and young women in accessing reproductive health: Promoting partnerships between young people and health care providers International Journal of Gynecology and Obstetrics 94, $350-356$.

Bekaert, Sarah (2005). Adolescents and Sex. Cornwall: Radcliffe Publishing Ltd.

Berrick, J.D., Gilbert, N. (1991). With the Best of Intentions. The Child Sexual Abuse Prevention Movement. New York: The Guilford Press. 
Casas, Lidia. (2005 a). Confidentiality of medical information, the right to health and sexual consent of adolescents REV. SOGIA (2009 b). Annual Report on Human Rights in Chile Facts 2008, Women's rights Chile: Universidad Diego Portales.

Center for Reproductive Rights and University of Toronto International Programme on Reproductive and Sexual Health Law (2002). Bringing Rights to Bear: An Analysis of the Work of UN Treaty Monitoring Bodies on Reproductive and Sexual Rights New York.

Centre for Reproductive Rights (2006), Court sets precedent, stopping Kansas Attorney General's effort to invade teen privacy. Available: http://www.reproductiverights.org/tools/print_page.jsp.

Chilean Code of Medical Ethics (Codigo de Etica Medica) (2006). Available http://www.colegiomedico.cl/area_gremial.asp?ids=353.

Chilean Criminal Code (Codigo Penal) (2009). Available: http://www.ben.cl/ll/lmsolicitadas/cr.

Chilean Parliament (2002) Report of the Commission on the Constitution, Legislation and Justice on the proposed law that modifies the Criminal Code, the Criminal Procedures Code and the Criminal Process Code, on the issue of crimes of child pornography, Issue No. 2906-07, Session 39, Tuesday, September 10th, 2002.

Cocca, Carolyn E. (2004). Jailbait. The Politics of Statutory Rape Laws in the United States. New York: State University of New York Press.

Committee on Child Psychiatry (1989). How Old is Old Enough? The Ages of Rights and Responsibilities New York: Brunner/Mazel Publishers

Committee on Economic, Social and Cultural Rights (2004). Concluding Observations: Chile. 26/11/2004.

Committee on Economic, Social and Cultural Rights (2000). General Comment 14.

Committee on Economic, Social and Cultural Rights (2000). General Comment 24.

Committee on the Rights of the Child (2003). Adolescent health and development in the context of the Convention on the Rights of the Child: 01/07/2003.

Committee on the Rights of the Child. (2002). Concluding Observations: Chile CRC/C/15/Add.173.

Constitution of the Republic of Chile. (2008). Available: http://www.bcn.cl/lc/cpolitica/index_html.

Constitutional Court of Colombia. (2006). Case C-355-06.

Constitutional Court of South Africa. (2006). Case CCT 54/06.

Convention on the Elimination of All Forms of Discrimination Against Women (CEDAW) (1979). Available: http://www.un.org/womenwatch/daw/cedaw/cedaw.htm .

Cook, R.J., Erdman, J.N., Dickens, B.M. (2007). Respecting adolescents' confidentiality and reproductive and sexual choices. Int J Gynaecol Obstet.

Cook, R.J., Dickens, B.M., and Fathalla, M. (2003). Reproductive health and human rights. Integrating medicine, ethics and law. Oxford: Clarendon Press, Oxford University Press.

Court of Appeals of Santiago. (2004) Rol No. 10592-03.

Department of Justice, Canada (2007). Frequently Asked Questions: Age of Consent to Sexual Activity. Available: http://www.justice.gc.ca/en/dept/clp/faq.html .

English, Abigail., Ford, Carol A. (2007). More Evidence Protects the Need to Protect Confidentiality in Adolescent Health Care Journal of Adolescent Health 40, 199-200.

European Court of Human Rights. (1992). Open Door Counselling and Dublin Well Woman v. Ireland 15 E.H.R.

Foucault, Michel. (1982). The History of Sexuality: Will to Knowledge. Harmondsworth: Penguin.

Gillick v West Norfolk and Wisbech Area Health Authority. (1986). Gillick v West Norfolk and Wisbech Area Health Authority AC 112. Available: http://www.hrcr.org/safrica/childrens_rights/Gillick_WestNorfolk.htm.

Gonzalez, M. I., Aguirre, M. L., Tapia, J. (2005). Profile of sexuality counselling assistants in an adolescent centre Rev Chil Pediatr 76 (6), 573-579.

INJUV (2003). Third national questionnaire on youth Chile.

International Covenant on Civil and Political Rights. (1976). Available: http://www.unhchr.ch/html/menu3/b/a_ccpr.htm (March 23 1976).

International Covenant on Economic, Social and Cultural Rights. (1976). Available: http://www.unhchr.ch/html/menu3/b/a_cescr.htm (3 January 1976). 
Jejeebhoy, S. J., Bott, S. (2005). Non-consensual sexual experiences of young people in developing countries: an overview. In Jejeebhoy, S. et al (Eds.) Sex Without Consent. Young People in Developing Countries London, New York: Zed Books.

Jenkins, P. (1998). Moral Panic. Changing Concepts of the Child Molester in Modern America New York: Yale University Press.

Kimmel, M. (2005). Men, Masculinity, and the Rape Culture. In Buchwald et al (Eds.) Transforming a Rape Culture USA: Milkweed Editions, 139 - 157.

Kirby, D. B., Laris, B.A., Rolleri, L. A. (2007). Sex and HIV Education Programs: Their Impact on Sexual Behaviours of Young People Throughout the World Journal of Adolescent Health 40, 206-217.

Law 20.084. (2005) Establishes a system of responsibility for adolescents who infringe the criminal law. Chile.

Lehrer, J. A., Pantell, Robert., Tebb, Kathleen., Shafer, Mary-Ann. (2007). Foregone Health Care Among U.S. Adolescents: Associations between Risk Characteristics and Confidentiality Concern Journal of Adolescent Health 40,218- 226.

Levine, Judith. (2002). Harmful to Minors. The Perils of Protecting Children from Sex Minnesota: University of Minnesota Press.

Ministerio Secretaria General de la Presidencia (2000). Constitutional Doctrine of President Eduardo Frei Ruiz-Tagle (Doctrina Constitucional del Presidente Eduardo Frei Ruiz-Tagle) Santiago, Chile.

National Commission on Political Prison and Torture (2004). Report of the National Commission on Political Prison and Torture Available: http://www.gobiernodechile.cl/comision_valech/index.asp.

National Commission on Truth and Reconciliation (1991). Report of the National Commission on Truth and Reconciliation. Available: http://www.ddhh.gov.cl/ddhh_rettig.html.

Northern Metropolitan Service (2005). Memorandum No 371. Santiago, Chile.

Packer, A. C. (1997 a). Preventing adolescent pregnancy: the protection offered by international human rights law The International Journal of Children's Rights 5: 47-76. The Netherlands: Kluwer Law International (2000 b). Sex Education: Child's Right, Parent's Choice or State's Obligation. In Heinze, E. (Ed.), Of Innocence and Autonomy. Children, sex and human rights (pp. 163-167). England: Ashgate.

Penal Process Code of Chile (2000). Law 19.696. Available: http://www.bcn.cl/leyes/pdf/actualizado/176595.pdf Santiago, Chile.

Pilon, M. (2001). Canada's Legal Age of Consent to Sexual Activity. Available: http://www.parl.gc.ca/information/library/PRBpubs/prb993-e.htm Library of Parliament, Canada.

Richard, N. (2007). The matter of feminism in Chile during the transition years (La problematica del feminismo en los anos de transicion en Chile), online: http://www.globalcult.org.ve/pub/Clacso2/richard.pdf .

Rubin, G. (1989). Thinking Sex: Notes for a Radical Theory of the Politics of Sexuality. In Pleasure and Danger. Exploring Female Sexuality (pp. 267-319) London: Pandora Press.

Sanitary Code of Chile. (1968). DFL-725, DTO-725. Available: http://www.bcn.cl/leyes/pdf/actualizado/5595.pdf Santiago, Chile.

Schaffner, L. (2005). Capacity, Consent, and the Construction of Adulthood. In Bernstein, E. \& Schaffner, L. (Eds.), Regulating Sex. The Politics of Intimacy and Identity (pp. 189-205). New York: Routledge.

The Alan Guttmacher Institute (1994). Sex and America's Teenagers New York and Washington.

United States District Court for the District of Kansas (2006). AID FOR WOMEN et al. vs. Nola Foulston et al., Case No. 03-1353-JTM, Memorandum Opinion and Order.

Villalba, C., Mihovilovic, V. (2007) Catholic Church. Guideline of national decisions (Iglesia Catolica. Pauta de las decisiones nacionales). Available: http://www2.netexplora.com/ConTintaNegra/ctn7/iglesia.htm .

\section{Notes}

Note 1. Chilean Criminal Code (Codigo Penal) (2009). Available: http://www.bcn.cl/lc/lmsolicitadas/cr, articles 361, 362 and 366 bis.

Note 2. Casas, Lidia. (2005). Confidentiality of medical information, the right to health and sexual consent of adolescents REV. SOGIA, p. 95. 
Note 3. Chilean Parliament (2002) Report of the Commission on the Constitution, Legislation and Justice on the proposed law that modifies the Criminal Code, the Criminal Procedures Code and the Criminal Process Code, on the issue of crimes of child pornography, Issue No. 2906-07, Session 39, Tuesday, September 10th, 2002, p. 83

Note 4. Northern Metropolitan Service (2005). Memorandum No 371. Santiago, Chile.

Note 5. Penal Process Code of Chile (2000). Law 19.696. Available: http://www.bcn.cl/leyes/pdf/actualizado/176595.pdf Santiago, Chile, article 180. According to Chilean law, prosecutors are responsible to lead investigations. They can investigate themselves or delegate the investigation of tasks that they believe will clarify the facts to the police.

Note 6. However, it must be noted that Chilean law does provide mechanisms to avoid investigations, through "temporary filing", which enables prosecutors to - as the name indicates - temporarily file a case, when there is a lack of information that would be able to lead to the clarification of the facts. See Penal Process Code of Chile, supra, note 5, article 167.

Note 7. Law 20.084 (2005) Establishes a system of responsibility for adolescents who infringe the criminal law. Chile, article 4.

Note 8. Law 20.084, supra, note 7, article 4.

Note 9. Law 20.084, supra, note 7, article 4.

Note 10. Pilon, M. (2001). Canada's Legal Age of Consent to Sexual Activity. Available: http://www.parl.gc.ca/information/library/PRBpubs/prb993-e.htm Library of Parliament, Canada.

Note 11. National Commission on Truth and Reconciliation (1991). Report of the National Commission on Truth and Reconciliation. Available: http://www.ddhh.gov.cl/ddhh rettig.html See also National Commission on Political Prison and Torture (2004). Report of the National Commission on Political Prison and Torture Available: http://www.gobiernodechile.cl/comision_valech/index.asp

Note 12. For further information on feminism in Chile, see Richard, N. (2007). The matter of feminism in Chile during the transition years (La problematica del feminismo en los anos de transicion en Chile), online: http://www.globalcult.org.ve/pub/Clacso2/richard.pdf.

Note 13. Paramount among these legal changes are: 1) The 1999 Constitutional reform, which added the sentence "Men and women are equal before the law", to the equality clause. (Law 19.611, 9 June 1999). 2) The establishment of the crime of human trafficking (Law 19.409, 31 August 1995). 3) The modification of the crime of rape, to now include vaginal, anal and oral rape, as well as recognition of male and female victims (Law 19.617, July 12 1999) 4) The recognition of the right of pregnant teenagers and teenage mothers to continue their education (Law 19.688, July 10 2000). 5) The prohibition of discrimination based on HIV/AIDS (Law 19.779, January 7 2002) 6)The establishment of sexual harassment in the work place (Law 20.005, March 18, 2005) 7) The law on violence within families (Law 20.066, September 22, 2005).

Note 14. For further information on the Catholic Church in Chile and its conservative influence, see Villalba, C., Mihovilovic, V. (2007) Catholic Church. Guideline of national decisions (Iglesia Catolica. Pauta de las decisiones nacionales). Available: http://www2.netexplora.com/ConTintaNegra/ctn7/iglesia.htm.

Note 15. Casas, Lidia (2009). Annual Report on Human Rights in Chile Facts 2008, Women's rights Chile: Universidad Diego Portales, p. 345.

Note 16. Committee on Economic, Social and Cultural Rights (2004). Concluding Observations: Chile. 26/11/2004, paragraph 15.

Note 17. Committee on the Rights of the Child (2002). Concluding Observations: Chile CRC/C/15/Add.173, paragraph 41.

Note 18. Committee on the Rights of the Child, supra, note 17, paragraph 7.

Note 19. Committee on the Rights of the Child, supra, note 17, paragraph 7.

Note 20. Committee on the Rights of the Child, supra, note 17, paragraph 29.

Note 21. Court of Appeals of Santiago (2004) Rol No. 10592-03.

Note 22. Court of Appeals of Santiago. Supra, note 21, paragraph 8.

Note 23. Jenkins, P. (1998). Moral Panic. Changing Concepts of the Child Molester in Modern America New York: Yale University Press, p. 4.

Note 24. Jenkins, P., supra note 23, p. 14.

Note 25. Constitutional Court of South Africa (2006). Case CCT 54/06, paragraph 24. 
Note 26. Jejeebhoy, S. J., Bott, S. (2005). Non-consensual sexual experiences of young people in developing countries: an overview. In Jejeebhoy, S. et al (Eds.) Sex Without Consent. Young People in Developing Countries London, New York: Zed Books, 3- 45, p.38.

Note 27. Jejeebhoy, S. J., Bott, Sarah., supra note 26, p.3.

Note 28. Schaffner, L. (2005). Capacity, Consent, and the Construction of Adulthood. In Bernstein, E. \& Schaffner, L. (Eds.), Regulating Sex. The Politics of Intimacy and Identity (pp. 189-205). New York: Routledge, p. 197.

Note 29. Levine, Judith. (2002). Harmful to Minors. The Perils of Protecting Children from Sex Minnesota: University of Minnesota Press, p. 71.

Note 30. Schaffner, Laurie, supra note 28, p. 197.

Note 31. Levine, Judith, supra note 29, p. 71.

Note 32. Levine, Judith, supra note 29, p. 71.

Note 33. Berrick, J.D., Gilbert, N. (1991). With the Best of Intentions. The Child Sexual Abuse Prevention Movement. New York: The Guilford Press, p.2.

Note 34. Bekaert, Sarah (2005). Adolescents and Sex. Cornwall: Radcliffe Publishing Ltd., p. 35

Note 35. Bekaert, Sarah, supra note 34, p. 37.

Note 36. Cocca, Carolyn E. (2004). Jailbait. The Politics of Statutory Rape Laws in the United States. New York: State University of New York Press, p.2.

Note 37. Rubin, G. (1989). Thinking Sex: Notes for a Radical Theory of the Politics of Sexuality. In Pleasure and Danger. Exploring Female Sexuality (pp. 267-319) London: Pandora Press, 267-319, p.290

Note 38. Levine, Judith, supra note 29, p. 72

Note 39. Cocca, Carolyn E., supra note 36, p. 3

Note 40. Schaffner, Laurie, supra note 28, p. 203

Note 41. Levine, Judith, supra note 29, p. 77

Note 42. Levine, Judith, supra note 29, p. 85

Note 43. Bekaert, Sarah, supra note 34, p. 36

Note 44. Foucault, Michel (1982). The History of Sexuality: Will to Knowledge. Harmondsworth: Penguin

Note 45. Cook, R.J., Dickens, B.M., and Fathalla, M. (2003). Reproductive health and human rights. Integrating medicine, ethics and law. Oxford: Clarendon Press, Oxford University Press, p. 102 -105.

Note 46. Chilean Criminal Code, supra note 1, article 363.

Note 47. Casas, Lidia, supra note 2, p. 10.

Note 48. INJUV (2003). Third national questionnaire on youth Chile, p. 27

Note 49. INJUV, supra note 48, p. 28

Note 50. INJUV, supra note 48, p. 28

Note 51. INJUV, supra note 48, p. 28

Note 52. Bekaert, Sarah, supra note 34, p. 41

Note 53. Bekaert, Sarah, supra note 34, p. 41.

Note 54. Gillick v West Norfolk and Wisbech Area Health Authority. (1986). Gillick v West Norfolk and Wisbech Area Health Authority AC 112. Available: http://www.hrcr.org/safrica/childrens_rights/Gillick_WestNorfolk.htm.

Note 55. Gillick v West Norfolk and Wisbech Area Health Authority, supra note 54, p. 11.

Note 56. Gillick v West Norfolk and Wisbech Area Health Authority, supra note 57, p. 21.

Note 57. United States District Court for the District of Kansas (2006). AID FOR WOMEN et al. vs. Nola Foulston et al., Case No. 03-1353-JTM, Memorandum Opinion and Order

Note 58. Centre for Reproductive Rights (2006), Court sets precedent, stopping Kansas Attorney General's effort to invade teen privacy. Available: http://www.reproductiverights.org/tools/print_page.jsp.

Note 59. United States District Court for the District of Kansas, supra note 57.

Note 60. United States District Court for the District of Kansas, supra note 57, p. 38-39 
Note 61. United States District Court for the District of Kansas, supra note 57.

Note 62. Committee on the Rights of the Child (2003). Adolescent health and development in the context of the Convention on the Rights of the Child: 01/07/2003, paragraph 11.

Note 63. Constitution of the Republic of Chile (2008). Available: http://www.bcn.cl//c/cpolitica/index_html .

Note 64. Chilean Code of Medical Ethics (Codigo de Etica Medica) (2006). Available http://www.colegiomedico.cl/area_gremial.asp?ids=353.

Note 65. Chilean Code of Medical Ethics, supra note 64, article 27.

Note 66. Chilean Code of Medical Ethics, supra note 64, article 38.

Note 67. Sanitary Code of Chile (1968). DFL-725, DTO-725. Available: http://www.bcn.cl/leyes/pdf/actualizado/5595.pdf Santiago, Chile, article 20.

Note 68. Penal Process Code, supra note 5, article 177.

Note 69. Chilean Criminal Code, supra note 1, articles 361-362.

Note 70. Bekaert, Sarah, supra note 34, p. 42

Note 71. Lehrer, J. A., Pantell, Robert., Tebb, Kathleen., Shafer, Mary-Ann. (2007). Foregone Health Care Among U.S. Adolescents: Associations between Risk Characteristics and Confidentiality Concern Journal of Adolescent Health 40,218- 226, at p. 218. See also English, Abigail., Ford, Carol A. (2007). More Evidence Protects the Need to Protect Confidentiality in Adolescent Health Care Journal of Adolescent Health 40, 199-200, p. 199.

Note 72. Casas, Lidia, supra note 2, p. 101.

Note 73. The Alan Guttmacher Institute (1994). Sex and America's Teenagers New York and Washington

Note 74. Lehrer, Jocelyn A., Pantell, Robert., Tebb, Kathleen., Shafer, Mary-Ann, supra note 71, p. 224.

Note 75. Constitution of the Republic of Chile, supra note 63, paragraph 1.

Note 76. European Court of Human Rights (1992). Open Door Counselling and Dublin Well Woman v. Ireland 15 E.H.R.

Note 77. Article 10 of the European Convention protects the right to freedom of expression and to receive and impart information.

Note 78. Committee on the Rights of the Child (2003). Adolescent health and development in the context of the Convention on the Rights of the Child: 01/07/2003, paragraph 28.

Note 79. Casas, Lidia, supra note 2, p. 110.

Note 80. Packer, A. C. (1997 a). Preventing adolescent pregnancy: the protection offered by international human rights law The International Journal of Children's Rights 5: 47-76. The Netherlands: Kluwer Law International, p. 47

Note 81. Gonzalez, M. I., Aguirre, M. L., Tapia, J. (2005). Profile of sexuality counselling assistants in an adolescent centre Rev Chil Pediatr 76 (6), 573-579.

Note 82. Kirby, D. B., Laris, B.A., Rolleri, L. A. (2007). Sex and HIV Education Programs: Their Impact on Sexual Behaviours of Young People Throughout the World Journal of Adolescent Health 40, 206-217. See also Advocates for Youth and the Sexuality. (2001). Toward a Sexually Healthy America: Roadblocks Imposed by the Federal Government's Abstinence-Only-Until-Marriage Program. New York: SEICUS

Note 83. Kirby, D. B., Laris, B.A., Rolleri, L. A., supra note 82.

Note 84. Department of Justice, Canada (2007). Frequently Asked Questions: Age of Consent to Sexual Activity. Available: http://www.justice.gc.ca/en/dept/clp/faq.html.

Note 85. Constitution of the Republic of Chile, supra note 63, article 19 No. 9.

Note 86. Constitutional Court of Colombia (2006). Case C-355-06

Note 87. Constitutional Court of Colombia, supra note 86.

Note 88. Constitutional Court of Colombia, supra note 86, p. 252/650

Note 89. International Covenant on Economic, Social and Cultural Rights (1976). Available: http://www.unhchr.ch/html/menu3/b/a_cescr.htm (3 January 1976).

Note 90. Committee on Economic, Social and Cultural Rights (2000). General Comment 14.

Note 91. Committee on Economic, Social and Cultural Rights, supra note 90, paragraph 12.

Note 92. Committee on Economic, Social and Cultural Rights, supra note 90, paragraph 12b. 
Note 93. Committee on Economic, Social and Cultural Rights (2000). General Comment 24, p. 25

Note 94. Constitution of the Republic of Chile, supra note 63, article 19.2

Note 95. Constitution of the Republic of Chile, supra note 63, article 19.2; American Convention on Human Rights (1969). Available: http://www.hrcr.org/docs/American_Convention/oashr.html (November 22, 1969), article 24; International Covenant on Civil and Political Rights (1976). Available: http://www.unhchr.ch/html/menu3/b/a_ccpr.htm (March 23 1976), article 2.

Note 96. Center for Reproductive Rights and University of Toronto International Programme on Reproductive and Sexual Health Law (2002). Bringing Rights to Bear: An Analysis of the Work of UN Treaty Monitoring Bodies on Reproductive and Sexual Rights New York, chs. 4-5.

Note 97. Ministerio Secretaria General de la Presidencia (2000). Constitutional Doctrine of President Eduardo Frei Ruiz-Tagle (Doctrina Constitucional del Presidente Eduardo Frei Ruiz-Tagle) Santiago, Chile, p. 102.

Note 98. Ministerio Secretaria General de la Presidencia, supra note 97, p. 103.

Note 99. Ministerio Secretaria General de la Presidencia, supra note 97, p. 103.

Note 100. Committee on Child Psychiatry (1989). How Old is Old Enough? The Ages of Rights and Responsibilities New York: Brunner/Mazel Publishers, p. 6

Note 101. Constitutional Court of Colombia, supra note 86.

Note 102. Constitutional Court of Colombia, supra note 86, page 284/650.

Note 103. Baker, T., Hobcraft, G. (2006). Special needs of adolescent and young women in accessing reproductive health: Promoting partnerships between young people and health care providers International Journal of Gynecology and Obstetrics 94, 350 - 356, p. 352. See also, Packer, A.C. (2000). Sex Education: Child's Right, Parent's Choice or State's Obligation. In Heinze, E. (Ed.), Of Innocence and Autonomy. Children, sex and human rights (pp. 163-167). England: Ashgate, p. 169

Note 104. Packer, A.C., supra note 80, p. 169

Note 105. Cook, R.J., Erdman, J.N., Dickens, B.M. (2007). Respecting adolescents' confidentiality and reproductive and sexual choices. Int J Gynaecol Obstet., p. 1.

Note 106. Kimmel, M. (2005). Men, Masculinity, and the Rape Culture. In Buchwald et al (Eds.) Transforming a Rape Culture USA: Milkweed Editions, 139 - 157, p. 141 - 142.

Note 107. Packer, A. C., supra note 80, p. 169.

Note 108. Convention on the Elimination of All Forms of Discrimination Against Women (CEDAW) (1979). Available: http://www.un.org/womenwatch/daw/cedaw/cedaw.htm, article 1. 